\title{
Analisis Kemampuan Komunikasi Matematis Mahasiswa melalui Penerapan Blended Learning pada Mata kuliah Geometri
}

\author{
Nishbah Fadhelina \\ Program Studi Pendidikan Matematika, Universitas Samudra \\ E-mail: nishbah@unsam.ac.id
}

\begin{tabular}{l}
\hline Article Info \\
\hline Article History \\
Received: 2021-01-12 \\
Revised: $2021-02-01$ \\
Published: $2021-03-23$
\end{tabular}

Keywords:

Mathematical

Communication;

Blended Learning;

Geometri.

\begin{abstract}
This study aims to determine how students' mathematical communication skills apply blended learning in geometry courses. This research uses a qualitative approach and descriptive research type. The instrument used was a test of mathematical communication skills. The subjects research were second semester students of the Universitas Samudra, Mathematics Education study program. The results showed that blended learning was going well, it could be seen from the average percentage of communication skills students are on the writing indicator (written text) is $90 \%$ that belongs to the category very good, drawing, is $80 \%$ which belongs to the category good and mathematical expressions is $65 \%$ that also belongs to good category,. The conclusion of this research is that blended learning can develop mathematical communication skills.
\end{abstract}

\begin{tabular}{l}
\hline Artikel Info \\
\hline Sejarah Artikel \\
Diterima: 2021-01-12 \\
Direvisi: 2021-02-01 \\
Dipublikasi: 2021-03-23 \\
\\
Kata kunci: \\
Komunikasi matematis; \\
Blended Learning; \\
Geometri.
\end{tabular}

\begin{abstract}
Abstrak
Penelitian ini bertujuan untuk mengetahui bagaimana kemampuan komunikasi matematis mahasiswa dengan menerapkan blended learning pada mata kuliah geometri . Penelitian ini menggunakan pendekatan kualitatif dan jenis penelitian deskriptif. Instrumen yang digunakan yaitu tes kemampuan komunikasi matematis. Subjek penelitian yaitu mahasiswa semester II program studi Pendidikan matematika universitas Samudra. Hasil penelitian menunjukkan blended learning berjalan dengan baik, dapat dilihat dari persentase rata-rata kemampuan komunikasi siswa berada pada indikator menulis (written text) di kategori sangat baik yaitu $90 \%$, dan menggambar (drawing), berada di kategori baik yaitu, 80\%, dan ekspresi matematika (matematical ekpression) juga ada di kategori baik yaitu, 65\%. Simpulan penelitian ini adalah pembelajaran dengan blended learning dapat mengembangkan kemampuan komunikasi matematis.
\end{abstract}

\section{PENDAHULUAN}

Kemampuan komunikasi matematis penting dikuasai siswa, sebab dalam mempelajari matematika siswa dituntut untuk memiliki kemampuan mengkomunikasikan gagasan dengan simbol, skema, tabel, grafik, atau diagram untuk memperjelas keadaan atau masalah, menunjukkan kemampuan dalam membuat, menafsirkan, dan menyelesaikan model matematika dalam pemecahan masalah, dan memiliki sikap menghargai kegunaan matematika dalam kehidupan sehari-hari, dan kemampuan komunikasi matematika merupakan salah satu indikator untuk memenuhi tuntutan tersebut (Fadhelina, 2018).

Komunikasi matematis didefinisikan oleh beberapa penulis dengan cara berbeda, namun memiliki pengertian yang hampir sama. Baird (Riasari, 2007) mengemukakan bahwa komunikasi adalah suatu proses penyampaian dan penerimaan hasil pemikiran individu melalui simbol. Kemampuan komunikasi matematis dapat diartikan sebagai kemampuan siswa dalam membaca masalah matematika secara komprehensif, mampu mengembangkan bahasa dan simbol matematika, baik secara tulisan maupun secara lisan (Dewi dan Biladina, 2021). Suhendra (Pane, Jaya, dan Lubis. 2018) mendefinisikan kemampuan komunikasi matematis adalah suatu kemampuan untuk mengungkapkan ide atau gagasan matematis dengan bahasa sendiri. Komunikasi merupakan salah satu bagian esensial dari matematika dan Pendidikan matematika. Komunikasi matematis diartikan sebagai sebuah cara untuk menyampaikan atau membagikan ide dan menjelaskan pemahaman siswa. Melalui komunikasi, sebuah ide akan menjadi objek dari pemikiran. NCTM (Riasari, 2018) menyatakan ketika siswa ditantang untuk menyampaikan pemikiran mereka ke orang lain secara lisan maupun tulisan, mereka belajar untuk menyampaikan lebih jelas, meyakinkan, dan lebih tepat dalam penggunaan bahasa matematis mereka,. Indikator kemampuan komunikasi matematis, menurut Jakabscin (Ansari, 2003) diklasifikasikan ke dalam tiga kelompok, yaitu: 
1. Pemunculan model konseptual, seperti gambar, diagram, tabel dan grafik (aspek drawing),

2. Membentuk model matematika (aspek mathematical expression)

3. Argumentasi verbal yang didasari pada analisis terhadap gambar dan konsep-konsep formal (aspek written text)

Kadir (Hodiyanto, 2017) menjelaskan bahwa pengukuran kemampuan komunikasi matematis siswa dilakukan dengan memberikan skor terhadap kemampuan siswa dalam memberikan jawaban soal dengan menggambar (drawing), membuat ekspresi matematik (mathematical expression), dan menuliskan jawaban dengan bahasa sendiri (written texts).

Alternatif untuk mengoptimalkan kemampuan komunikasi matematis siswa adalah dengan menerapkan model pembelajaran blended learning. Prinsip dasar dari model pembelajaran Blended Learning adalah mengoptimalkan pengintegrasian komunikasi lisan yang ada pada pembelajaran tatap muka dengan komunikasi tertulis pada pembelajaran online (Riasari,2018). Hinkelmen \& Paul Gruba (Cahyadi, 2012) mengemukakan bahwa pendekatan blended learning secara substantif mencoba menggabungkan "pendekatan campuran" yang terdiri atas pembelajaran berbasis online, pembelajaran tatap-muka (face to face) dan pembelajaran berbasis naskah (paper-based learning). Wardani, Toenlioe, dan Wedi (2018) menyatakan bahwa penggabungan yang dilakukan secara baik antara pengajaran tatap muka dimana pengajar dan pebelajar bertemu langsung dan melalui media online yang bisa diakses kapanpun. Penggabungan pembelajaran tatap muka (face-toface) dengan e-learning tersebut disebabkan karena terbatasnya waktu dan mudah membuat siswa merasa cepat bosan dalam proses pembelajaran serta tuntutan perkembangan teknologi yang semakin luas. Syahrin (2015) mengemukakan beberapa keunggulan Blended Learning, yaitu; (1) peserta didik leluasa untuk mempelajari materi pembelajaran secara mandiri dengan memanfaatkan materi-materi yang tersedia secara online, (2) peserta didik dapat melakukan diskusi dengan pengajar atau peserta didik di luar tatap muka, (3) kegiatan pembelajaran yang dilakukan peserta didik di luar jam tatap muka dapat dikelola dan dikontrol dengan baik oleh pengajar, (4) pengajar dapat meminta peserta didik membaca materi atau mengerjakan tes yang dilakukan sebelum pembelajaran (5) pengajar dapat menambahkan materi pengayaan melalui fasilitas internet, (6) pengajar dapat menyelenggarakan kuis, memberikan balikan, dan memanfaatkan hasil tes dengan efektif, (7) peserta didik saling berbagi file dengan siswa lain.

Bahan ajar pada blended learning dalam pertemuan online dengan bantuan komputer dapat diprogram secara interaktif dan memiliki keunggulan karena program komputernya dapat digunakan untuk mengajarkan konsep yang sulit disampaikan secara manual, menuntut tingkat ketepatan yang amat tinggi, memerlukan banyak sekali pengulangan (repetisi), dan memerlukan Latihan eksplorasi konsep (Supianti, 2016). Blended learning menggunakan teknologi informasi sebagai media pembelajaran (Usman, 2018), yang mempermudah mahasiswa memahami konsep- konsep matematika khususnya geometri.

Geometri merupakan salah satu mata kuliah wajib yang diajarkan di program studi Pendidikan matematika Fakultas Keguruan dan Ilmu Pendidikan Universitas Samudra. Mata kuliah Geometri secara garis besar membahas konsep bangun datar dan bangun ruang serta unsur-unsurnya. Menurut Budiarto (2000: 65) geometri didefinisikan sebagai cabang matematika yang mempelajari tentang titik, garis, bidang dan benda-benda ruang serta sifatsifatnya, ukuran-ukurannya dan hubungan dengan yang lain. Hanafi (2017) menyatakan bahwa geometri adalah salah satu cabang dari matematika yang sangat erat hubungannya dengan kehidupan nyata. Geometri merupakan ilmu yang mempelajari tentang bentuk, ruang beserta sifatnya.

Mempelajari materi geometri membutuhkan visualisasi yang tinggi karena bersifat abstrak, perlu alat peraga atau media pembelajaran manual atau digital untuk membantu mahasiswa memvisualisasikan materi untuk memahami konsepnya. Nur'aeni (2008) menyatakan bahwa geometri merupakan cabang ilmu matematika yang paling sulit karena membutuhkan pemahaman dan penalaran konsep yang baik. Pembelajaran geometri dengan blended learning memanfaatkan bahan ajar interaktif yang didesain dalam bentuk program dan aplikasi komputer untuk mempermudah mahasiswa memahami konsep-konsep geometri diharapkan dapat mengembangkan kemampuan komunikasi matematis siswa. Berdasarkan uraian diatas, penulis berusaha untuk mengetahui bagaimana kemampuan komunikasi matematis siswa berdasarkan indikator kemampuan menulis, menggambar, dan ekspresi matematika.

\section{METODE PENELITIAN}

Penelitian ini menggunakan pendekatan kualitatif dan jenis penelitian deskriptif. Subyek pada penelitian ini adalah mahasiswa semester II program studi Pendidikan matematika Fakultas Keguruan dan Ilmu Pendidikan universitas Samudra tahun ajaran 2019/2020 yang berjumlah 26 orang. Instrumen yang digunakan untuk mengumpulkan data adalah tes kemampuan komunikasi matematis. Sebelum tes diberikan kepada mahasiswa, dilakukan uji kualitas pengembangannya dengan uji validitas dan realibilitas, setelah data terkumpul dilakukan analisis data dengan tahapan berikut: menganalisis persentase, mereduksi data, menyajikan data, dan menarik kesimpulan. Indikator kemampuan komunikasi matematis yaitu: 1. menulis (written text)., 2. Menggambar (drawing)., dan 3. Ekspresi matematika (matematical expression). Instrument yang digunakan pada penelitian ini adalah 6 soal tes yang 
sesuai dengan indikator kemampuan komunikasi matematis dengan skor maksimal 60. Selanjutnya data yang dikumpulkan dianalisis dengan cara: (1) memberi skor mentah pada setiap jawaban, (2) menghitung skor total masing-masing mahasiswa berdasarkan indikatornya, (3) menentukan nilai persentase kemampuan komunikasi matematis masing-masing mahasiswa dengan menggunakan rumus:

$$
\mathrm{NP}=\frac{\mathbb{R}^{\prime}}{S M} X 10036
$$

(Purwanto, 2010)

Dengan NP = nilai persen yang dicari, $\mathrm{R}=$ skor mentah yang diperoleh mahasiswa, $\mathrm{SM}=$ skor maksimum ideal, 100 = bilangan tetap, (4), menghitung skor ratarata dengan menggunakan rumus:

$$
\text { Rata- rata }=\frac{\text { Jumlah skor tiap indikaton }}{\text { Jumlah mahasiswa }}
$$

dengan kriteria sebagai berikut :

$0 \leq$ Nilai < 20 : Sangat Kurang

$20 \leq$ Nilai $<40$ : Kurang

$40 \leq$ Nilai $<60$ : Cukup

$60 \leq$ Nilai $<80$ : Baik

$80 \leq$ Nilai $\leq 100$ : Sangat Baik

(Sudjana, 2001)

(5) Menentukan tingkat kemampuan mahasiswa berdasarkan kriteria tingkat kemampuan mahasiswa dengan table kriteria sebagai berikut:

Tabel 1. Kriteria Tingkat Kemampuan Mahasiswa Melalui Tes

\begin{tabular}{cc}
\hline Interval Skor $(\%)$ & Kategori \\
\hline $81-100$ & Sangat Baik \\
\hline $61-80$ & Baik \\
\hline $41-60$ & Cukup \\
\hline $21-40$ & Kurang \\
\hline $0-20$ & Sangat Kurang \\
\hline & (Riduwan, 2015)
\end{tabular}

\section{HASIL DAN PEMBAHASAN}

A. Hasil Penelitian

Hasil penelitian yang diperoleh dari data tes kemampuan komunikasi mahasiswa berdasarkan indikator menulis (written text), menggambar (drawing), dan ekspresi matematika (matematical expression) yang diberikan kepada 26 mahasiswa dapat dilihat pada tabel 2 berikut:

Tabel 2. Data Skor Hasil Tes Kemampuan Komunikasi Matematis Secara Keseluruhan

\begin{tabular}{|cc|}
\hline Data & Jumlah \\
\hline Sampel & 26 \\
\hline Skor tertinggi & 90 \\
\hline Skor terendah & 77 \\
\hline Rata-rata & $\mathbf{7 9}$
\end{tabular}

Tabel diatas menunjukkan hasil tes yang diberikan kepada sampel sejumlah 26 orang, perolehan rata-rata skor mahasiswa secara keseluruhan adalah 79. Skor tertinggi adalah 90 dan skor terendah 75. Nilai rata-rata indikator kemampuan komunikasi matematis dapat dilihat pada gambar berikut ini:

\section{Indikator \\ KemampuanKomunikasi Matematis}

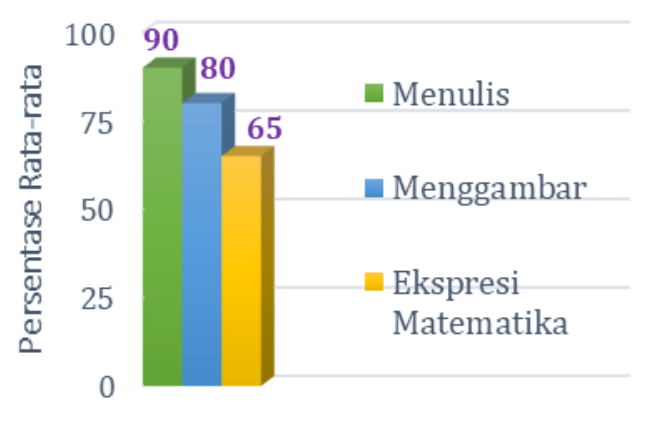

Gambar 1. Grafik Indikator Kemampuan Komunikasi Matematis Siswa

Grafik diatas menunjukkan persentase komunikasi matematis pada indikator menulis (written text) sebesar 90\% (sangat baik), menggambar (drawing) sebesar 80\%, dan ekspresi matematika (matematical expression) sebesar $65 \%$.

\section{B. Pembahasan}

Kemampuan komunikasi matematis mahasiswa dalam penelitian ini adalah kesanggupan siswa dalam menyampaikan ide-ide matematisnya secara tertulis berdasarkan 3 indikator kemampuan komunikasi matematis yaitu menggambar (drawing), menulis (written texts). dan ekspresi matematika (mathematical expression). Untuk mengukur kemampuan komunikasi matematika mahasiswa pada ketiga indikator diatas, diberikan 6 soal essay yang masing-masing soal mewakili satu indikator komunikasi matematis. Berdasarkan tabel kriteria tingkat kemampuan mahasiswa, hasil tes kemampuan komunikasi mateamatis mahasiswa dikategorikan pada sangat kurang dengan interval skor 0-20, kategori kurang dengan interval skor 21-40, kategori cukup dengan interval skor 41-60, kategori baik dengan interval skor 61-80, dan kategori sangat baik dengan interval skor 81-100.

Hasil penelitian ini menunjukkan bahwa kemampuan komunikasi matematis mahasiswa dengan menerapkan blended learning pada mata kuliah geometri berada pada kategori baik dan sangat baik. Penelitian sejenis oleh Riasari (2018) menunjukkan bahwa Blended learning dapat mengembangkan kemampuan komunikasi 
matematis siswa sehingga mereka mampu dalam menggunakan ide matematikanya, memahami dalam memecahkan masalah matematika yang dituangkan baik dalam lisan maupun tulisan. Sejalan dengan hasil penelitian oleh Febrian dan Astuti (2019) yang menunjukkan bahwa persepsi mahasiswa terhadap penerapan blended learning positif. Hasil penelitian Afria (Novita dan Astuti, 2016) juga menunjukkan bahwa kemampuan komunikasi matematis siswa dalam pembelajaran Blended learning tergolong baik. Pembelajaran offline dan online yang dilaksankan secara bergantian dapat mengungkapkan ide-ide matematis siswa melalui lisan dan tulisan deengan benar.

Hasil tes yang diberikan kepada sampel, diperoleh rata-rata skor mahasiswa secara keseluruhan adalah 79 (tingkat kemampuan baik). Skor tertinggi adalah 90 (tingkat kemampuan sangat baik) dan skor terendah 75 (tingkat kemampuan baik).

Persentase kemampuan komunikasi matematis mahasiswa menunjukkan indikator menulis (written text) sebesar 90\% (sangat baik). Kemampuan menulis mahasiswa menempati urutan tertinggi dengan kategori sangat baik dibandingkan dua indicator lainnya, hampir semua mahasiswa mampu berargumentasi verbal yang didasari pada analisis terhadap gambar dan konsep-konsep formal. Kemampuan komunikasi matematis mahasiswa pada indikator menggambar (drawing) sebesar 80\%, dikategorikan dengan kemampuan baik, menunjukkan lebih dari setengah jumlah mahasiswa mampu memunculkan model konseptual, seperti gambar, diagram, tabel dan grafik. Kemampuan komunikasi matematis mahasiswa pada Indikator ekspresi matematika (matematical expression) sebesar 65\% berada pada kategori baik. Indikator ini berada pada urutan paling rendah dari tiga indicator kemampuan komunikasi matematis yang diujikan, hal ini mengindikasikan bahwa ekspresi matematika masih sulit dikuasi seluruh mahasiswa.

\section{KESIMPULAN DAN SARAN}

\section{A. Simpulan}

Berdasarkan hasil penelitian blended learning yang diterapkan pada mata kuliah geometri mampu mengembangkan kemampuan komunikasi matematis mahasiswa. Persentase rata-rata kemampuan komunikasi siswa mengindikasikan bahwa indikator menulis (written text) berada di kategori sangat baik yaitu 90\%, indikator menggambar (drawing) berada di kategori baik yaitu, $80 \%$, serta indikator ekspresi matematika (matematical ekpression) juga berada pada kategori baik yaitu, 65\%. Sehingga dapat disimpulkan kemampuan komunikasi matematis bisa dikembangkan melalui pembelajaran blended learning.

\section{B. Saran}

Berdasarkan hasil penelitian saran yang perlu disampaikan ini antara lain sebagai berikut: hendaknya dalam melaksanakan evaluasi kemampuan komunikasi matematis siswa dilakukan untuk indikator kemamampuan lisan dan tulisan, dan peneliti selanjutnya dapat melakukan penelitian serupa pada mata kuliah lain yang dapat mengembangkan kemampuan komunikasi matematis mahasiswa dengan model pembelajaran yang sesuai.

\section{DAFTAR RUJUKAN}

Ansari, B. I. 2003. Menumbuh kembangkan Kemampuan Penalaran dan Komunikasi Matematik Siswa Sekolah Menengah Umum (SMU) melalui Strategi Think Talk Write. Bandung: Disertasi Sekolah Pasca Sarjana UPI.

Astuti, D.A., \& Novita, D., 2019. Blended Learning Terhadap Kemampuan Komunikasi Matematis. Prosiding Sendika: Vol 5, No 1

Astuti, P., \& Adrian., 2019. Blended Learning Syarah: Bagaimana Penerapan dan Persepsi Mahasiswa. Jurnal Gantang Volume 4 No 2. 111-119.

Budiarto, M.T. 2000. Pembelajaran Geometri dan Berpikir Geometri. Dalam prosiding Seminar Nasional Matematika "Peran Matematika Memasuki Milenium III". Surabaya: FMIPA ITS.

Cahyadi, A., 2017. Menuju holistik pembelajaran campuran (blended learning). Holistik Journal For Islamic Social Sciences IAIN Syekh Nurjati Cirebon. Volume 2, Nomor 1. 1-15.

Dewi, H.L., Biladina, S.G., 2021. Komunikasi Matematis Dan Blended Learning: Analisis Kemampuan Statistika Mahasiswa Di Masa Pandemi Covid19. Seminar Nasional Pendidikan Matematika Vol 2 No 1, 221-228

Fadhelina, N., 2018. Pengembangan Bahan Ajar Berbasis Model Pembelajaran Kooperatif Tipe Jigsaw Untuk Meningkatkan Kemampuan Komunikasi Matematis dan Berpikir Kreatif Siswa SMP. Tesis. Medan: Program Pascasarjana Universitas Negeri Medan

Hanafi, M. A., 2017. Deskripsi Kesulitan Belajar Geometri Mahasiswa Program Studi Pendidikan Matematika Fakultas Keguruan Dan Ilmu Pendidikan Universitas Cokroaminoto Palopo. Prosiding Seminar Nasional Vol 3 Nomor 1. 373-283.

Hodiyanto, 2017. Kemampuan Komunikasi Matematis Dalam Pembelajaran Matematika. AdMathEdu . Vol.7 No.1.9-18. 
Munzadi, M., 2018. Pengaruh Blended Learning Berbasis Rotation Model Terhadap Motivasi Dan Hasil Belajar Geografi Siswa Ma Matholiul Anwar Lamongan. Jurnal Pendidikan Geografi Undiksha, Vol. 6, No. 3. 125-132

Nur'aeni, E. 2008. Teori Van Hiele dan Komunikasi Matematik (Apa, Mengapa, dan Bagaimana). Dalam Semnas Matematika dan Pendidikan Matematika. 2008, Tasikmalaya, Indonesia. 2 138.

Pane, S.N., Jaya, I., Lubis, M.S., 2018. Analisis Kemampuan Komunikasi Matematis Siswa Pada Materi Penyajian Data Di Kelas Vii Mts Islamiyah Medan T.P 2017/2018. AXIOM Vol. VII, No. 1, Januari - Juni 2018, 907-109

Purwanto, N., 2010. Prinsip-prinsip dan Teknik Evaluasi Pengajaran. Bandung: Remaja Rosda Karya

Riasari, D., 2018. Peranan Model Pembelajaran Matematika Berbasis Blended Learning Terhadap Komunikasi Matematis Siswa Dalam Materi Statistik Pada Sman 1 Tapung. Jurnal Pendidikan Tambusai. Volume 2 Nomor 4, 813820
Riduwan. (2015). Belajar Mudah Penelitian untuk Guru-Karyawan dan Peneliti Pemula.Bandung: Alfabeta

Sudjana, N. (2001). Penilaian Hasil Proses Belajar Mengajar. Bandung : Remadja Rosdakarya.

Suhendra (Pane, Jaya, dan Lubis. 2018) mendefinisikan kemampuan komunikasi matematis adalah suatu kemampuan untuk mengungkapkan ide atau gagasan matematis dengan bahasa sendiri.

Supianti, I.I., 2016. Dampak Penerapan E-Learning Dalam Pembelajaran Matematika Terhadap Kemandirian Belajar Mahasiswa. Jurnal Teori dan Riset matematika (TEOREMA) Vol. 1 No. 1.

Usman., 2018. Komunikasi Pendidikan Berbasis Blended Learning Dalam Membentuk Kemandirian Belajar. Jurnalisa Vol 04 Nomor 1. 136-150.

Wardani, D.N., Toenlioe, A.J.E., \& Wedi, A., 2018. Daya Tarik Pembelajaran Di Era 21 Dengan Blended Learning. JKTP Volume 1, Nomor 1. 13-18. 